\title{
Output, Money, and Prices: The Case of Jordan
}

\author{
Torki M. Al-Fawwaz ${ }^{1} \&$ Khaled Mohammed Al-Sawai'e ${ }^{2}$ \\ ${ }^{1}$ Finance and Economic Department, Faculty of Finance and Business Administration, AL Al-bayt University, \\ Mafraq, Jordan \\ 2 Jordanian Customs Department, Jordan \\ Correspondence: Torki M. Al-Fawwaz, Finance and Economic Department, Faculty of Finance and Business \\ Administration, AL Al-bayt University, Mafraq, P.O. Box 1117, zip code 11947, Amman, Jordan. Tel: \\ 962-77-671-4955. E-mail: alfawwaz@aabu.edu.jo
}

Received: July 24, 2012

doi:10.5539/ibr.v5n12p223
Accepted: November 6, 2012

Online Published: November 12, 2012

\begin{abstract}
The relationship between gross domestic product growth, money supply, and prices was not important for the formulation of monetary policy in Jordan. Taking into account the importance of these three variables, we analyzed the short run relationship between money, the price, and the gross domestic product (GDP) growth for the Jordanian economy. Time series methods were used for the annual data for the period 1976-2009. The results indicate that there is not an existing short-term relationship between money supply (M1) and GDP growth in Jordan. However, the monetary policy has not had any impact on the Jordanian macroeconomic variables, while it found out that there is a causal relationship from money supply to inflation, with low degree of $(0.21)$.
\end{abstract}

Keywords: monetary policy, gross domestic product (GDP), money supply, prices, vector autoregressive model

\section{Introduction}

Monetary policy plays an important role in the economic growth of the country. The relationship between money supply, income, and prices is still a controversial issue particularly between the Keynesians and Monetarists. The Keynesians emphasize that a change in income cause changes in money stocks through the demand for money, which means that there exists a unidirectional causality from income to money without any feedback.

The Monetarists, on the other hand, claim that money plays an significant role, and also consider money supply to be the main factor leading to changes in income and prices. Therefore, the direction of causation runs from money to income and prices without any feedback (Shams, 2012).

The causal relationship between money, price, and output has been investigated by different researchers especially after the seminal paper by Sims (1972). The empirical studies have provided conflicting evidence on this issue, such as: Miller (1991), Friedman and Kuttner (1992), Jamie Emerson (2005), Herwartz and Reimers (2006), Saatcioglu and Korap (2008), Barth and Bannett (1974), Lee and Li (1983), Jarrah (1996), Gilman and Nakov (2004).

The current study attempts to test the relationship causality among the three variables in the context of the Jordanian economy.

The goal of this the study is to determine the relationship among growth of GDP, money supply and price levels in Jordan, using annual data for the period 1976-2010 for the nominal gross domestic product, money supply (M1), and the consumer prices index (P) to express the income, money and prices respectively.

This study attempts to test the causality among the three variables as follows:

1 - The money supply causes the growth of GDP and prices.

2 - The price causes the growth of GDP and money supply.

The rest of the paper is arranged as follows. The second section provides literature review. The data and methodology are presented in third section. The fourth section discusses the results of the study. The final section contains the conclusion. 


\section{Literature Review}

Money supply, national income, and prices are considered three major variables in macroeconomic that play an essential role in determining the rate of economic growth. A number of studies showed the causal relationship between money supply and income. On the other hand, there was still consistency concerning of the results of these studies, some studies showed unidirectional causality either from income to money or from money to income, while others are bi-direction causal. Some did not find any evidence of causal relationship.

Fatima and Iqbal (2003) examined the relative impact of monetary and fiscal policies on the economic growth in five Asian countries: Pakistan, India, Thailand, Indonesia, and Malaysia. The results showed a binary causal trend between fiscal policy and economic growth, as well as between monetary policy and economic growth for Thailand. In the case of Indonesia, the causal direction was single from the monetary policy to economic growth and fiscal policy to economic growth. The estimated results for Malaysia showed a single causal direction of policy variables to economic growth. In the case of Pakistan, it found that the monetary policy has an impact on economic growth. As for India, the study showed a single causal direction of monetary policy to economic growth.

Mishra et al. (2010) tested the causality between money, price, and output in India. They found that a bidirectional causality between money supply and output, and a unidirectional causality from price level to money supply and output. Husain and Rashid (2006) attempt an investigation of the causal relationship between money and income and between money and prices in Pakistan. They revealed evidence of a unidirectional causality from income to money and from money to prices.

Al-Rjoub (2004) examined the output effect of monetary policy in Jordan. The result showed that each time series explained the preponderance of its own past values. M2 explains $85 \%$ of its forecast error variance, industrial production index explains $15.2 \%$ of the forecast error variance in 2 periods, whereas the money supply explains $7 \%$ of the forecast error variance of industrial index. Majid (2007) study the causality relationship between monetary aggregates, output and prices in the case of Malaysia. The results indicate that a bidirectional causality running between monetary aggregates, M2 and M3 and output, whereas there is a unidirectional causality running from monetary aggregate, $\mathrm{M} 1$ and output.

Saatcioglu and Korap (2008) examine the long-run relationships between monetary aggregates, prices, and real output for the Turkish economy. The study found that monetary aggregates are endogenous for the long-run evolution of prices and real income. Ghazali et al. (2008) examine the relationship between money and prices in Malaysia. They have emphasized that there is a long-run equilibrium relationship between money supply with prices. Toda-Yamamoto causality tests find that there is uni-directional causality running from money supply to CPI.

Suleman and Hussain (2009) examined the relationship between money supply, government expenditure, output and prices in Pakistan. The study indicates that government expenditure and inflation are negatively related to economic growth in the long run, while M2 positively impacts on economic growth. Jiranyakul, K. (2009) studied the relationship among money, prices, and aggregate output in Thailand. Indicate that a stable long-run relationship between real money demand and aggregate output when M3 is used as monetary aggregate.

Chimobi and Uche (2010) tested the empirical relationship between money, prices, and output in Nigeria. The results revealed that money supply was seen to Granger cause both output and prices, and (M2) to have a strong causal effect on the real output and prices. Sharma and Cheng (2010) examined the causality between prices, output, and money in India. They viewed that a unidirectional causality between money and output, the study also found a unidirectional causality between money and prices.

Shawagfeh, W. (2011) examined the relationship among output, money and prices in Jordan. The results showed that broad money supply, price and real GDP are co-integrated. Also, there is a unidirectional causality that runs from money to real GDP; however, results indicate no impact in the short run. Sharma et al. (2010) studied the causality between prices, output and money in India. They indicate that output and prices do not granger cause money supply reflecting exogeneity of money supply. Mishra et al. (2010) tested the causality between money, price and output India. The study showed that a bidirectional causality between money supply and output, and unidirectional causality from price level to money supply and output.

\section{Methodology and Data}

The data used are gross domestic product (GDP) growth, and money supply (M1) and the consumer price index (P) to express the income, money and prices respectively, for the period 1976-2010. We obtained the data from annual reports of the Central Bank of Jordan (CBJ). All our empirical tests have been carried out using the 
E-views econometrics package.

A time series is stationary if its mean and variance is constant over time. This means that the series does not have an upward or downward trend over time. Standard estimation procedures cannot be applied to the model that contains a nonstationary variable. Also, the nonstationary time series has the possibility of spurious regression. So, we should test if a series is stationary or not before using it in a model (Kim et al 2003). Then we transform nonstationary series by taking the first differences, or the number of differencing operation it takes to make the series stationary.

According to Hall et al. (1999), the researchers had to identify the number of lagged periods to add to the regression, through a sufficient lags to remove any serial correlation in the residuals. But, if they choose lag length that are too long, the estimates become imprecise. If the sample size is not large enough, estimating many parameters will need a lot of degrees of freedom (Gujarati, 1995).

A unit root test has been applied to check stationary of money supply M1, growth gross domestic product (GDP), and prices. Stationarity condition has been tested using Augmented Dickey Fuller (ADF) [Dickey and Fuller $(1979,1981)$ as follows:

$$
\begin{gathered}
\Delta G D P_{t}=\alpha_{0}+\alpha_{1} t+\alpha_{2} G D P_{t-1}+\sum_{i=1}^{n} \gamma_{i} \Delta G D P_{t-i}+\varepsilon_{t 1} \\
\Delta M 1_{t}=\beta_{0}+\beta_{1} t+\beta_{2} M 1_{t-1}+\sum_{i=1}^{n} \delta_{i} \Delta M 1_{t-i}+\varepsilon_{t 2} \\
\Delta P_{t}=\lambda_{0}+\lambda_{1} t+\lambda_{2} P_{t-1}+\sum_{i=1}^{n} \psi_{i} \Delta P_{t-i}+\varepsilon_{t 3}
\end{gathered}
$$

Our next step is to estimate the direction of both long-run and short-run Granger causality by using a cointegration test, when there is integrated of order one direction; the error correction model (ECM) (Engle and Granger 1987) is used. According to the following model:

$$
\Delta G D P_{t}=\gamma_{1}+\delta_{1} C E_{t-1}+\sum_{i=1}^{n} \alpha_{i} \Delta G D P_{t-i}+\sum_{i=0}^{n} \beta_{i} \Delta M 1_{t-i}+\sum_{i=0}^{n} \mu_{i} \Delta P_{t-i}+\varepsilon_{t}
$$

Where $\delta_{1}$ is error term from the long-run equation, $\alpha_{i}, \beta_{i} \mu_{i}$ that are respectively: transactions, income, cash, and prices that will be appreciated, and $\gamma_{1}$ constant and $\varepsilon_{t}$ error term or (Impulses) and CE t- 1 which is a lag of errors. The following tests (serial correlation, functional form, normality, heteroskedasticity and structural stability) should be used to make sure the quality of the model.

While if it's not cointegrated then autoregressive method will be used to test the Granger causality as follows:

$$
y_{t}=a_{i}+\sum_{t=1}^{m} \lambda_{i} y_{t-i}+\sum_{t=1}^{m} \mu_{i} x_{t-i}+u_{t}
$$

Where $y$ is a matrix of endogenous variables which include gross domestic product, money supply, and prices, and $x$ is the exogenous variables, and $a$ is an intercept.

In the trace test, the null hypothesis of $\gamma$ cointegrating vectors against the alternative hypothesis of $n$ cointegrating vectors. The maximum eigenvalue test, on the other hand, examines the null hypothesis of exactly $r$ cointegrating relations against the alternative of $r+1$ cointegrating relations.

\section{Results}

In this study, the relationship between output, money and prices in Jordan has been examined, by using time series methods. The Augmented Dickey-Fuller (ADF) (Dickey \& Fuller, 1981) test is used to determine the stationarity of time series. The results of the unit-root tests are reported in Table 1 which indicated that the gross domestic product growth, money supply, and prices are I(1).

Second step is to test the cointegration analysis and determine the order of cointegration of the equation by using Johansen method $(1988,1995)$, and since Johansen method is sensitive for autocorrelation in residuals, it will be determined by the appropriate lag lengths to estimate a model that is not suffering from autocorrelation problem. Schwarz criterion is used to determine the lag length periods (lagged one period), then testing autocorrelation lengths for specific lag, and for choosing acceptable test of cointegration. We use Pantula (1989) principle to determine the co-integration rank. Three models results were estimated and presented in a statistical trace as shown in table 2 to choose the preferred model. In our case, model 2 is the preferred model. 
Table 1. The results of the unit root test by Augmented Dickey Fuller test (variables logarithm)

\begin{tabular}{|c|c|c|c|c|}
\hline & Variables & Model & ADF & lags \\
\hline & & \multicolumn{3}{|l|}{ Augmented Dickey Fuller test for levels } \\
\hline Gross Domestic Product (GDP) & $G d p$ & constant and a trend & -2.2624 & 1 \\
\hline Narrow money supply & M1 & constant and a trend & -2.270 & 1 \\
\hline \multirow[t]{2}{*}{ Consumer price index } & $P$ & Without a constant and without a trend & 1.895 & 2 \\
\hline & $\Delta$ & \multicolumn{3}{|c|}{ Augmented Dickey Fuller test for differences "First Difference" } \\
\hline Gross Domestic Product (GDP) & $G d p$ & constant and without a trend & $* * *-3.748$ & 0 \\
\hline Narrow money supply & $P$ & constant and without a trend & $* *-3.468$ & 0 \\
\hline Consumer price index & $P$ & constant and without a trend & $* * *-3.403$ & 1 \\
\hline
\end{tabular}

Note: $(*),(* *),(* *)$ indicate the rejection of null hypotheses in a level of $10 \%, 5 \%$ and $1 \%$ respectively.

Table 2. Cointegration Rank and Model Selection: Trace Statistics

\begin{tabular}{llll}
\hline & $\begin{array}{l}\text { MODEL } 2 \\
\text { (Without Constant "Without trend") in CE } \\
\text { and without Constant or trend in VAR }\end{array}$ & $\begin{array}{l}\text { MODEL } 3 \\
\text { Constant in CE and VAR and } \\
\text { without trend in CE and VAR }\end{array}$ & $\begin{array}{l}\text { MODEL } 4 \\
\text { Constant in CE and VAR and } \\
\text { without trend in CE and VAR }\end{array}$ \\
\hline $\mathrm{R}$ & VAR Lag Order Selection Criteria: SIC (Lag 1) & & \\
0 & $27.43(35.19)^{*}$ & $27.15(29.80)$ & $33.81(42.92)$ \\
1 & $14.59(20.26)$ & $14.47(15.49)$ & $16.03(25.87)$ \\
2 & $4.19(9.16)$ & $4.18(3.84)$ & $4.25(12.52)$ \\
\hline
\end{tabular}

Note: Figures in parentheses represent the critical value at the level of significance of $5 \% .{ }^{*}$ Includes the first case we encounter, we cannot then reject the null hypotheses.

The results of model 2 show non-presence of cointegrated. Table 3 indicates that the statistical trace and Maximal Eigenvalue, confirm these results. Since the variables are not integrated, we must use the unrestricted autoregressive vector model (VAR).

Table 3. Cointegration Test Results

\begin{tabular}{|c|c|c|c|}
\hline \multirow{2}{*}{ Null Hypotheses } & \multirow{2}{*}{ The Optimal lag } & \multicolumn{2}{|c|}{ Statistical Test } \\
\hline & & Trace Test & Eigenvalues Test \\
\hline & 1 & & \\
\hline$r=0$ & & 27.42540 & 12.83470 \\
\hline$r \leq 1$ & & 14.59071 & 10.39952 \\
\hline$r \leq 2$ & & 4.191185 & 4.191185 \\
\hline
\end{tabular}

The results of unrestricted VAR model for GDP, and money supply and prices level. VAR model is selected in one lag period, and the equation of GDP showed that the null hypothesis of no Granger causality from the real effective exchange rate to import of intermediate goods is accepted, and, therefore, does not extend the impact of money supply and the price level in the gross domestic product (GDP). The results of the equation of prices level showed that a money supply causes a high level of prices at the $5 \%$ level of significance. The equation is stable during the study period. This is confirmed by testing AR Roots Graph, which displays the three roots inside the circle, indicating that the model is stable and meets the requirements of stability as shown by Figure 1. Therefore, this model does not require any modification.

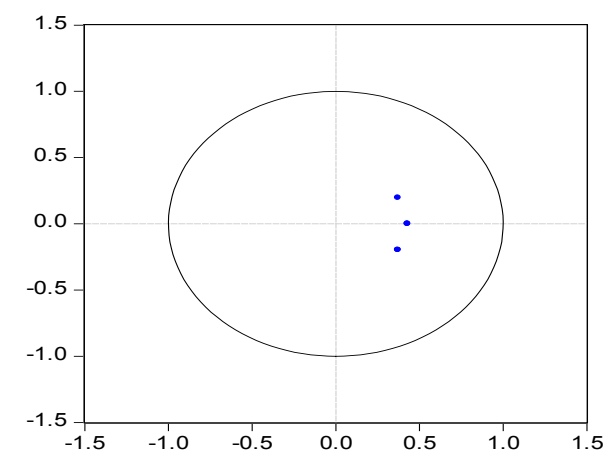

Figure 1. Inverse Roots of AR Characteristic Polynomial 


$$
\begin{aligned}
& \Delta \mathrm{gdp}=\underset{\mathrm{t}=[1.77959]}{0.289} \Delta \mathrm{gdp}_{\mathrm{t}-1}+\underset{[1.33362]}{0.179} \Delta \mathrm{ml}_{\mathrm{t}-1}+\underset{[0.99655]}{0.214} \Delta \mathrm{cpi} \mathrm{i}_{\mathrm{t}-1}+\underset{[1.80368]}{0.037}+\underset{[2.17701]}{0.127 \mathrm{C} 92} \\
& \Delta \mathrm{m} 1=-\underset{[-0.04275]}{0.010} \Delta \mathrm{gdp}_{\mathrm{t}-1}+\underset{[2.40208]}{0.444} \Delta \mathrm{ml}_{\mathrm{t}-1}+\underset{[0.09091]}{0.027} \Delta \mathrm{cpi} \mathrm{t}-1_{[1.74246]}+\underset{[-0.37484]}{0.049} \mathrm{C} 92 \\
& \Delta \mathrm{cpi}=\underset{[-1.90054]}{0.232} \Delta \mathrm{gdp}_{\mathrm{t}-1}+\underset{[2.08820]}{0.211} \Delta \mathrm{m}_{\mathrm{t}-1}+\underset{[2.71472]}{0.441} \Delta \mathrm{cpi}_{\mathrm{t}-1}+\underset{[2.12949]}{0.033} \underset{[-0.77685]}{0.034} \mathrm{C} 92
\end{aligned}
$$

Table 4. Results of Granger Causality in multivariate

\begin{tabular}{llllll}
\hline Dependent Variable & $\begin{array}{l}\text { Growth Delay } \\
\text { of GDP }\end{array}$ & $\begin{array}{l}\text { Factor } \\
\text { GDP Growth }\end{array}$ & $\begin{array}{l}\text { Growth Delay Factor } \\
\text { of Money Supply }\end{array}$ & $\begin{array}{l}\text { Growth Delay Factor } \\
\text { of the Price Level }\end{array}$ & $\begin{array}{l}\text { Common } \\
\text { Interest }\end{array}$ \\
\hline Money Supply Growth & 0.002 & 1.779 & 0.993 & 3.646 \\
Price Level Growth & $3.612^{*}$ & - & 0.008 & 0.009 \\
\hline
\end{tabular}

Note: $(*),(* *),(* *)$ indicate the moral degree of $1 \%$ and $5 \%$ and $10 \%$ respectively. Numbers are the calculated value for statistical $X^{2}$.

We conclude from table 4 the following:

1 - The money supply does not cause the growth of GDP, while causing the price.

2 - The price does not cause the growth of GDP and does not cause the money supply.

Table 5 illustrates the result of the variance decomposition of the gross domestic product for the horizon of 10 periods. The decomposition divided the variance into parts explained by each explanatory variable in the model. The second column contains the standard deviation, which is the forecast error of the growth of GDP for the forecast horizon. The remaining columns give the percentages of the variances of the money supply and prices level.

In the model of the growth of GDP, after 10 periods, the money supply changes the growth of GDP for approximately $10 \%$ of variation, while the price level can change the growth of GDP for approximately $3 \%$ of variation during the same period.

Table 5. The Results of GDP's Variance decomposition

\begin{tabular}{llll}
\hline \multirow{2}{*}{ Period } & \multirow{2}{*}{ Standard error } & Explanatory Percentage (\%) & \\
\cline { 3 - 4 } & & Money Supply & Prices Level \\
\hline 1 & 0.06 & 0.00 & 0.00 \\
2 & 0.06 & 5.39 & 2.04 \\
5 & 0.07 & 12.07 & 3.21 \\
10 & 0.07 & 12.20 & 3.21 \\
\hline
\end{tabular}

According to Alavalapati et al. (1996) the impulse response function estimates the impact of one single shock to explanatory variable on dependent variable for several periods in the future .In this study, the impulse response function provides the response of the of growth of GDP to a standardized one-unit shock in money supply and prices level. The mean responses and variances of the growth of GDP were obtained for 10 future periods.

Figure 2 shows the response growth of GDP to one unit impulse equal to one standard deviation of the money supply and prices level for future 10 periods.

Midline is the value of the impulse response average, which is a uniform size of the response. Money supply and prices shock impact have an importance for 3 periods on the GDP growth in Jordan. This shows the impact of money supply and prices shock on the GDP growth to be disappeared after about 6 periods. Also, a change in the variables' order did not change the response, so this result is only to arrange the GDP growth, money supply, and prices. 


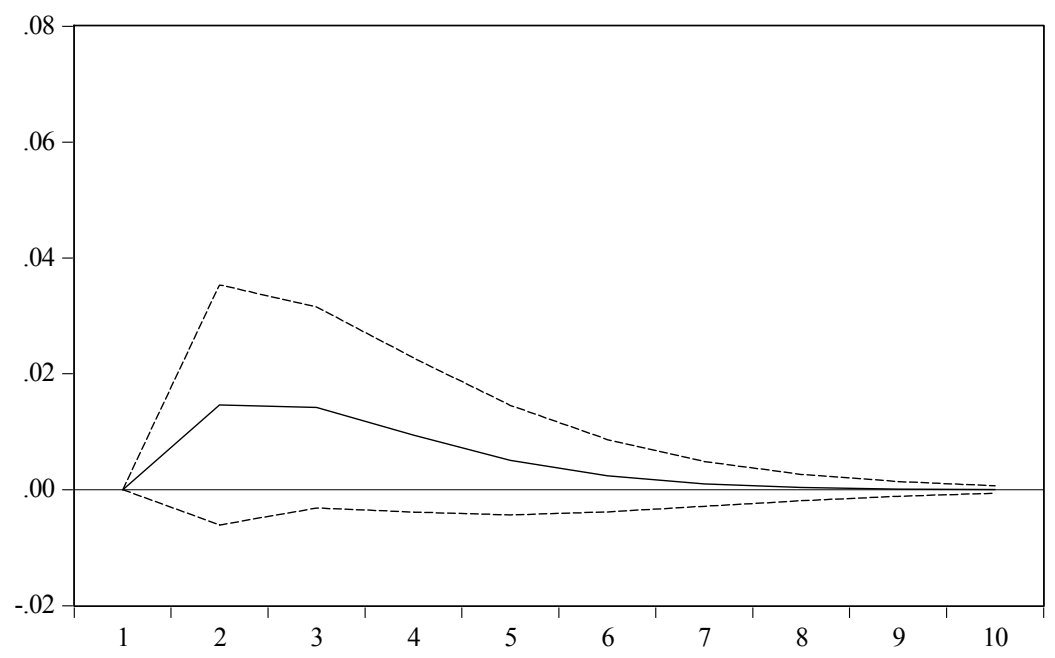

(A) Money Supply Shock

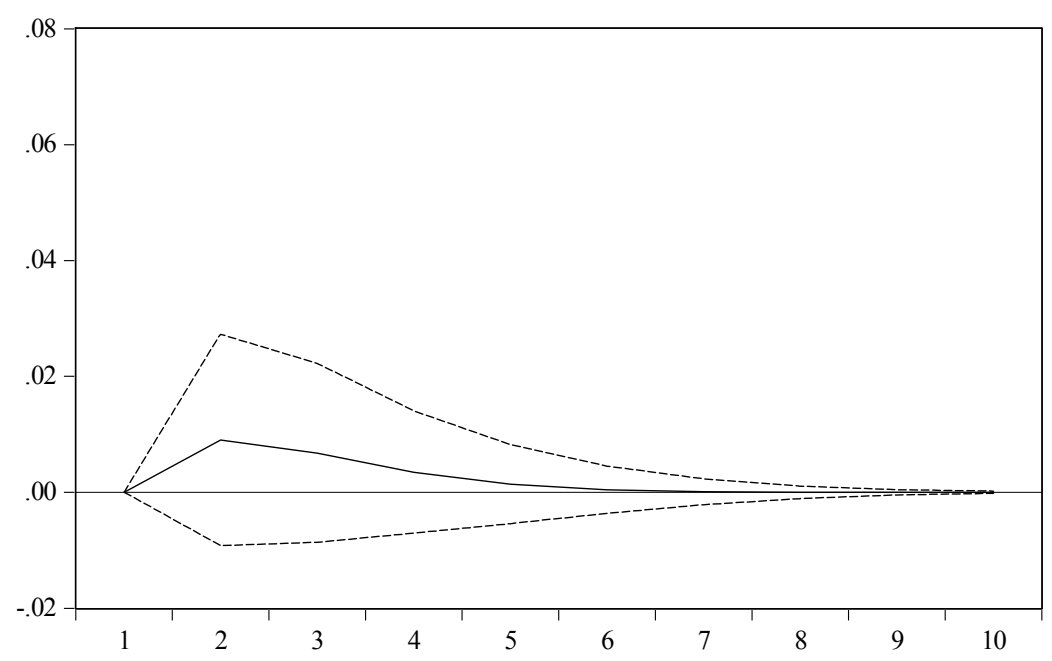

(B) Price Shock

Figure 2. GDP growth Response for one Standard Deviation Shock

\section{Conclusions}

This study discussed the short run causal relationship between growth of GDP, money supply and the prices in Jordan, through Autoregressive model (VAR). The results indicate a non-presence of a long-run relationship between the three variables. We conclude that monetary policy as a way to change the M1dose not have any important implications on changing the nominal income in Jordan in the short run. Based on that, we conclude that the monetary policy is not relatively effective in the short run and money supply as an external variable will cause price level movement and not in the GDP growth. Policy implications arising from this analysis indicate that monetary policy does not play a significant role in influencing the level of economic activity in Jordan. In short, an increase in money supply does not increase economic activity in Jordan.

\section{References}

Alavalapati, J., Luckert, M., \& Adamowicz, W. (1996). Short-term influences on Canadian wood pulp prices and exports. Canadian Journal of Forest Research, 26, 566-572. http://dx.doi.org/10.1139/x26-065

Al-Jarrah, M. (1996). Money, Income, and Prices in Saudi Arabia: A Cointegration and Causality Analysis. Pakistan Economic and Social Review, 34(1), 41-53.

Al-Rjoub, S. (2004). The Output Effect of Monetary Policy in Jordan: Using VAR. Dirasat Administrative Sciences, 31(2), 423-438.

Barth, J., \& Bannett, J. (1974). The Role of Money in the Canadian Economy: An Empirical Test. Canadian 
Journal of Economics, 7, 306-311. http://dx.doi.org/10.2307/134169

Chimobi, O. P., \& Uche, U. C. (2010). Money, Price and Output: A Causality Test for Nigeria. American Journal of Scientific Research, 8, 78-87.

Dickey, D. A., \& Fuller, W. A. (1981). Likelihood Ratio Statistics for Autoregressive Time Series with a Unit Root. Econometrica, 49, 1057-1072. http://dx.doi.org/10.2307/1912517

Fatima, A., \& Iqbal, A. (2003). The Relative Effectiveness of Monetary and Fiscal Policies an Econometric Study. Pakistan Economic and Social Review, XLI(1\&2), 93-116.

Friedman, B., \& Kuttner, K. (1992). Money, Income, Prices, and Interest Rates. The American Economic Review, 82, 472-492.

Ghazali, F. M. (2008). Linkage between Money and Prices: A Causality Analysis for Malaysia. International Business Research, 1(4), 82-87.

Gillman, M., \& Anton, N. (2004). Granger Causality of the Inflation-Growth Mirror in Accession Countries. Economics of Transition, 12(4), 653-682. http://dx.doi.org/10.1111/j.0967-0750.2004.00198.x

Gujarati, D. (1995). Basic Econometrics. (3rd ed.). New York: McGraw-Hill, Inc.

Hall, R., Lilien, D., Sueyoshi, G., Engle, R., Johnston, J., \& Ellsworth, S. (1999). E-Views manual. Irvine (CA): Quantitative Micro Software Inc.

Herwartz, H., \& Reimers, H. E. (2006). Long-Run Links among Money, Prices and Output: Worldwide Evidence. German Economic Review, 7(1), 65-86. http://dx.doi.org/10.1111/j.1468-0475.2006.00147.x

Husain, F., \& Rashid, A. (2006). Economic Liberalization and the Causal Relations among Money, Income, and Prices: The Case of Pakistan. Discussion Paper No.3, Center for Computational Social Sciences, University of Mumbai, January, pp.1-18. from http://mpra.ub.uni-muenchen.de/3195/1/MPRA_paper_3195.pdf, in India: An Empirical Investigation in the Frequency Domain.

Jamie, E. (2005). The Quantity Theory of Money: Empirical from the United States. Economics Bulletin, 5(2), $1-6$.

Jiranyakul, K. (2009). Relationship among money, prices and aggregate output in Thailand. Empirical Economics Letters, 8(11), 1063-1071.

Lee, S., \& Li, W. (1983). Money, Income, and Prices and their Lead-Lag Relationship in Singapore. Singapore Economic Review, 28, 73-87.

Majid, M. Z. A. (2007). Causal Link between Money, Output and Prices in Malaysia: An Empirical Re-Examination. Applied Econometrics and International Development, 7(1), 211-220.

Miller, S. (1991). Monetary Dynamics: An Application of Co-integration and Error-Correction Modeling. Journal of Money, Credit, and Banking, 23, 139-154. http://dx.doi.org/10.2307/1992773

Mishra, P. K., Mishra, U. S., \& Mishra, S. K. (2010). Money, Price and Output: A Causality Test for India. International Research Journal of Finance and Economics, 53, 26-36.

Pantula, G. (1989). Testing for Unit Roots in Time Series Data. Econometric Theory, 5(2), 256-271. http://dx.doi.org/10.1017/S0266466600012421

Saatcioglu, C., \& Korap, L. (2008). Long-Run Relations between Money, Prices and Output: The Case of Turkey. ZKÜ Sosyal Bilimler Dergisi, 4(7), 33-54.

Shams, N. (2012). Money, Income, and Prices in Bangladesh: A Cointegration and Causality Analysis. Journal of Economics and Sustainable Development, 3(7), 82-88.

Sharma, A., Kumar, A., \& Hatekar, N. (2010). Causality between Prices, Output and Money.

Shawagfeh, W. (2011). The Relationship between Output, Money, and Prices in Jordan: A Co integration Analysis. Business Sciences Series, 38(1), 257-267.

Sims, C. (1972). Money, Income and Causality. The American Economic Review, 62(4), 540-552.

Suleman, D., Wasti, S. K. A., Lai, I., \& Hussain, A. (2009). An Empirical Investigation between Money Supply Government Expenditure, Output \& Prices: the Pakistan Evidence. European Journal of Economics, Finance and Administrative Sciences, 17, 60-68. 